\title{
Preliminary Investigations of an Opposed Rotary Piston Compressor for the Air Feeding of a Polymer Electrolyte Membrane Fuel Cell System
}

\author{
Shikai Xing, Jianbing Gao,* Guohong Tian, Meng Zhao, and Chaochen Ma \\ Cite This: https://dx.doi.org/10.1021/acsomega.0c03347 \\ Read Online
}

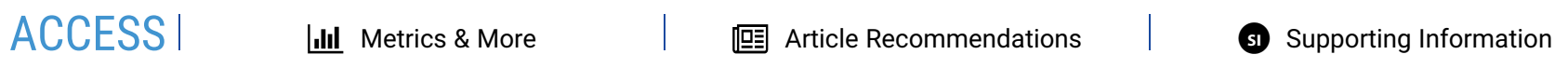

ABSTRACT: Automotive polymer electrolyte membrane fuel cell systems are attracting much attention, driven by the requirements of low automotive exhaust emissions and energy consumption. A polymer electrolyte membrane fuel cell system provides opportunities for the developments in different types of air compressors. This paper proposed an opposed rotary piston compressor, which had the merits of more compact structures, less movement components, and a high pressure ratio, meeting the requirements of polymer electrolyte membrane fuel cell systems. Preliminary performance evaluations of the opposed rotary piston compressor were conducted under various scenarios. This will make a

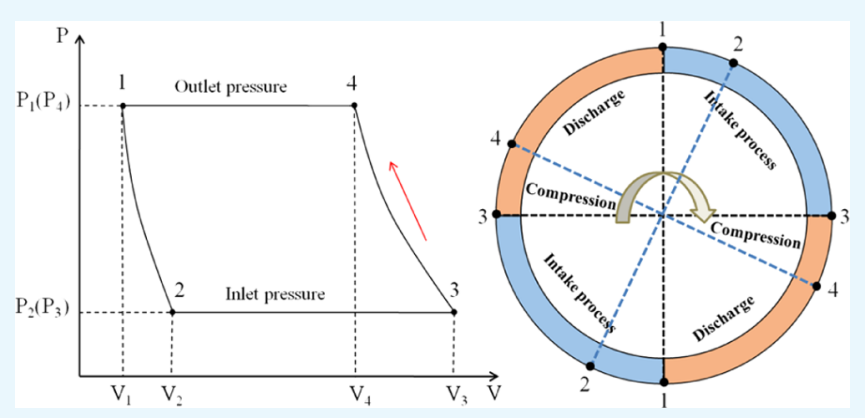
foundation for optimizations of outlet pipe layouts of the compressor. A three-dimensional numerical simulation approach was used; further, in-cylinder pressure evolutions, fluid mass flow rates, and $P-V$ diagrams were analyzed. It indicated that the cyclic period of the opposed rotary piston compressor was half of reciprocating piston compressors. The specific mass flow rate of the compressor is in the range of $0.094-0.113 \mathrm{~kg} \cdot(\mathrm{s} \cdot \mathrm{L})^{-1}$ for the given scenarios. Outlet ports 1 and 2 dominated the mass flow in the discharge process under scenarios 1, 3, and 4. In-cylinder pressure profiles show multipeaks for all of these scenarios. In-cylinder pressure increased rapidly in the compression process and part of the discharge process, which led to high energy consumption and low adiabatic efficiency. The maximum adiabatic efficiency is approximately $43.96 \%$ among the given scenarios.

\section{INTRODUCTION}

Under the pressure of fossil fuel consumption and environmental pollution caused by internal combustion engine powered vehicles, ${ }^{1-5}$ much attention is focused on polymer electrolyte membrane (PEM) fuel cell systems. PEM fuel cell systems are free of pollutants and have a high energy density. ${ }^{6-8}$ Meanwhile, high system efficiency and excellent low-temperature performance promote the applications of PEM fuel cells to automotive. 9 It was demonstrated that the energy consumed by air compressors reached $15 \%$ of the total energy in fuel cell systems. ${ }^{10}$ Therefore, high efficiency air compressors should be adopted to decrease the energy consumption. Meanwhile, the air compressors must be compact and light for automotive applications. Many types of air compressors were investigated for the fuel cell system applications, such as scroll compressors, lobe compressors, reciprocating piston compressors, Wankel compressors, screw compressors, and centrifugal compressors. ${ }^{11-14}$ Currently, there are no professional air compressors being available for fuel cell system applications.

Small-scale centrifugal compressors have been widely investigated because of their applications in turbocharged systems; however, the requirements of air compressors in PEM fuel cell systems are different from those in turbocharger systems. Qi et al. ${ }^{15}$ designed and researched a centrifugal compressor for an air supply system. The maximum efficiency and pressure ratio of this compressor were $83 \%$ and 2.2, respectively. Additionally, the compressor efficiency increased with rotation speed, and the mass flow rate was in the range of $0.022-0.068 \mathrm{~kg} / \mathrm{s}$. Mass flow rates of centrifugal compressors are significantly depends on the pressure ratio, and the mass flow range is limited by surge phenomenon that is an issue decelerating their applications to PEM fuel cell systems. Screw compressors have continuous sweeping motions, resulting of quiet operation with little pulsation. He et al. ${ }^{16}$ developed an oilfree twin-screw air compressor, which was designed for a truck fuel cell system. $P-V$ diagrams were analyzed to investigate the effects of rotation speed and discharge pressure on the compressor performance, such as energy consumption and compressor efficiency. The results indicated that the volumetric efficiency and isentropic efficiency of the compressor were 70 and $55 \%$ over discharge pressure of 2.0 bar and female rotor

Received: July 13, 2020

Accepted: September 9, 2020 
speed of $9000 \mathrm{rpm}$. Size of screw compressors is bigger than centrifugal and piston compressors, additionally, leakages in screw compressors are serious compared to other types of compressors. Leakages in screw compressor, mainly caused by rotor tip clearances and discharge end-face clearances, ${ }^{17}$ is a great factor deteriorating compressor performance. Maximum drop of the indicated power of the fuel cell system caused by leakages was approximately $20 \%$ under $3000 \mathrm{rpm}$.

Compared to other types of compressors, piston compressors have the advantages of their capability of providing high pressure air. Outlet pressures of piston compressors can be adjusted by the valve timing, which can effectively enlarge high efficiency regions. Outlet pressures of a piston compressor reached 13.0 bar by controlling intake and discharge valve timing. ${ }^{18}$ It can effectively decrease the compressor size, contributing to a higher competition of fuel cell vehicles to conventional ones. Kotlov et al. ${ }^{19}$ analyzed the performance of a reciprocating compressor using a numerical simulation method, indicating that optimizations of valve designs effectively improved the compressor efficiency. In-cylinder flows of a reciprocating compressor were conducted using dynamic numerical simulations by Mi et al. ${ }^{20} \mathrm{P}-V$ diagrams of the compressor were used to analyze the pressure loss over various rotation speeds. A low rotation speed decreased the pressure losses, but it led to serious vibrations, resulting of a shorter life time of compressors.

Air compressors have a significant impact on performances of fuel cell systems, which provide an opportunity of developing various types of compressors. Opposed rotary piston (ORP) compressors have oil free pistons, low noise, few moving parts, and compact structures. OTECHOS ${ }^{21}$ investigated a compressor owing similar structures as the ORP compressor, named centric reciprocating (CR) compressor. Energy consumption of the CR compressor was 15-20\% lower than screw compressors and reciprocating piston compressors. Caskey and Groll ${ }^{22}$ briefly analyzed a new rotary cylinder compressor that had a high volumetric efficiency and a small torque ripple. At the moment, there are not any professional compressors available for the fuel cell systems, and the research studies are few to date. So, much attention should be paid to the fuel cell compressors. In this paper, the performance of a new ORP compressor, aiming at providing air to PEM fuel cells, was investigated. To the authors' knowledge, there are not any reports about the performance investigations on this type of compressors. The ORP compressor is compact and can reach high pressure. Cyclic period of the ORP compressor is $180^{\circ}$ crank angle (CA), which means a higher mass flow rate compared to conventional reciprocating compressors in theory. Such that a smaller volume can be achieved if they are applied to the same fuel cell system. However, mass low rates and energy consumption of this compressor are still unknown. In this paper, the in-cylinder flow characteristics of the ORP compressor are explored over various scenarios, making a foundation of improving compressor structures (focused on the layouts of inlet and discharge pipes). The applications will significantly decrease the exhaust emissions and energy consumption from conventional vehicles.

The structure of this paper is organized as the following: (1) the compressor structures and components are introduced in detail, in addition, fluid domain movements during compressor operations are analyzed; (2) the numerical simulation approach of the compressor model are introduced, and calculation stability is analyzed to assess precisions in three-dimensional (3D) numerical simulations; (3) intake and discharge characteristics of the compressor over various scenarios are investigated, and the in-cylinder pressures are discussed; (4) $P-V$ diagrams are used to analysis the adiabatic efficiency and energy consumption of the compressor.

\section{MATERIALS AND METHODS}

The ORP compressor is restructured from an ORP engine, which is highly compact and has a high-power density. ${ }^{23}$

2.1. Structures and Operation Processes of the ORP Compressor. Detailed specifications of the ORP compressor are listed in Table 1. This compressor has four cylinders, four

Table 1. Specifications of the ORP Compressor

\begin{tabular}{ll}
\multicolumn{1}{c}{ specifications } & values \\
compressor type & ORP \\
cylinder number & 4 \\
piston number & 4 \\
displacement/L & 0.5468 \\
bore/mm & 59.5 \\
chord length of the piston end face $/ \mathrm{mm}$ & 59.0 \\
geometric angle of both end faces in piston/deg & 56 \\
inlet port number & 2 \\
outlet port number & 6
\end{tabular}

pistons, two inlet ports, six outlet ports, and two crank shafts. The displacement of the chamber is $0.5468 \mathrm{~L}$. The outlet pressure of the compressor can be adjusted by the exhaust port timing. Structures of the ORP compressor are shown in Figure 1. There are two pairs of air exchange systems in this compressor: outlet ports 1,2 , and 3 , inlet port 1 are nominated as system 1 ; outlet ports 4,5 , and 6 , inlet port 2 are nominated as system 2 . Operation processes of the two air exchange systems are synchronous. Pistons 1 and 3 are connected with shaft 1 , while pistons 2 and 4 are connected with shaft 2 , resulting of the same movements of cylinders 1 and 3, and the other two pistons are consistent. Movement profiles of the two shafts are in sinusoidal mode, as shown in Figure 2. Cylinder fluid movements of this compressor are different from reciprocating piston compressors ${ }^{24}$ because two end faces of each cylinder in this compressor are always moving, which is similar to Wankel compressors. ${ }^{25}$ Inlet and outlet port opening is controlled by piston movements. This compressor has a shorter cyclic period than reciprocating piston compressors, resulting of a higher mass flow rate. Therefore, the ORP compressor can be downsized to meet fuel cell system requirements.

Fluid domains of the compressor are shown in Figure 3. It has four cylinder domains (four bowls are included in each cylinder), two inlet pipe domains, and six outlet pipe domains. Figure 4 shows movements of the cylinder fluid domains as different time steps. Top dead centers are defined as positions where the cylinder volume is the smallest; the bottom dead centers (BDCs) are corresponding to the maximum cylinder volume. In addition, $\mathrm{CA}$ is defined as the positions of the gravimetric center the cylinder fluid. This compressor has two top dead centers (TDCs) and two BDCs, as shown in time step of 250 in Figure 4.

$P-V$ diagrams and CA phases under ideal conditions are shown in Figure 5. Pressure over point 4 is corresponding to the discharge pressure of this compressor, which can be adjusted by the three outlet ports. Energy consumption in theory per cycle is determined by the area of $1-2-3-4$. Arques ${ }^{26}$ presented $P-V$ diagrams of a reciprocating piston compressor, they were similar to that of this ORP compressor. However, the ORP compressor 

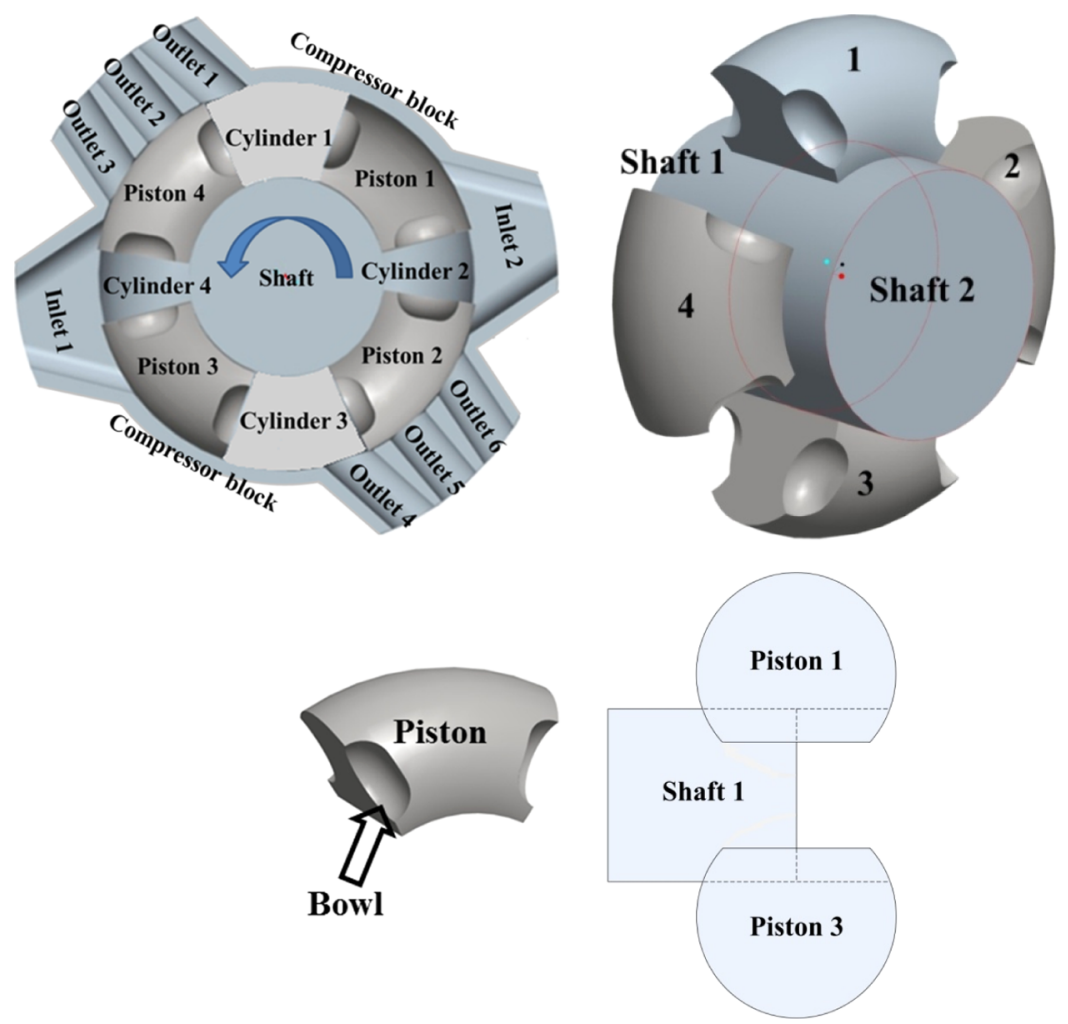

Figure 1. Structures of the ORP compressor.

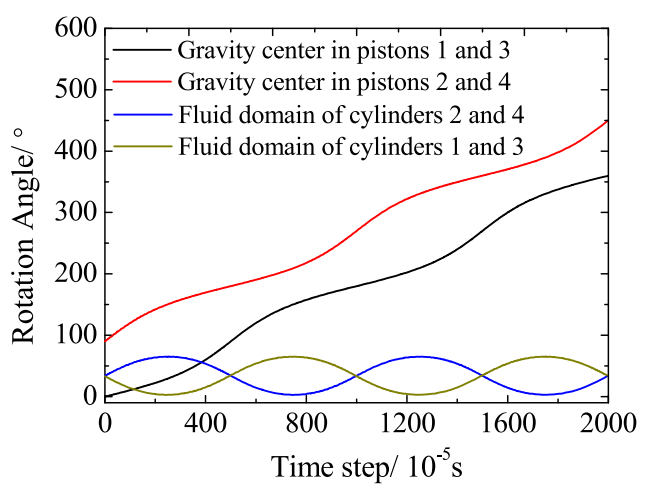

Figure 2. Movement profiles of the pistons and cylinder fluid domains.

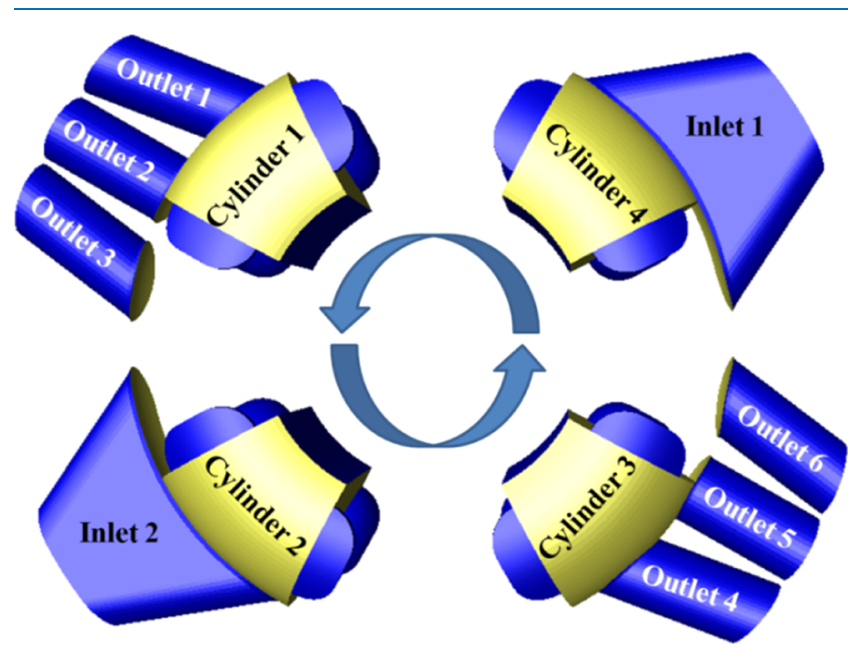

Figure 3. Fluid domains of the ORP compressor. has a shorter cyclic period; it means less time for air exchange. In these works, ${ }^{26,27}$ piston movements and speeds were indicators to evaluate compressor performance because the piston movements indicated cylinder volume change rates, which was one of the main factors determining in-cylinder pressure evolutions. However, cylinder volume change rates of the ORP compressor are determined by two adjacent piston movements, as shown in Figure 4.

2.2. 3D Simulation Theory. In this paper, $3 \mathrm{D}$ commercial numerical simulation software, Ansys Fluent, was used to calculate unsteady flow of the new ORP compressor, for example, in-cylinder pressure, mass flow rate, temperature distributions, and streamlines. Simulations of Ansys Fluent are based on the finite volume method. ${ }^{28}$ Renormalization group $k-\varepsilon$ model was used, and it can improve the accuracy of predicting rapidly strained flows and swirling flows. ${ }^{29}$ The transport equations of $k$ and $\varepsilon$ are shown in eqs 1 and 2.

$$
\begin{aligned}
& \frac{\partial}{\partial t}(\rho k)+\frac{\partial}{\partial x_{i}}\left(\rho k u_{i}\right) \\
& =\frac{\partial}{\partial x_{j}}\left[\left(\mu+\frac{\mu_{\mathrm{t}}}{\sigma_{\mathrm{k}}}\right) \frac{\partial k}{\partial x_{j}}\right]+P_{\mathrm{k}}+P_{\mathrm{b}}-\rho \varepsilon-Y_{\mathrm{M}}+S_{\mathrm{k}} \\
& \frac{\partial}{\partial t}(\rho \varepsilon)+\frac{\partial}{\partial x_{i}}\left(\rho \varepsilon u_{i}\right) \\
& =\frac{\partial}{\partial x_{j}}\left[\left(\mu+\frac{\mu_{\mathrm{t}}}{\sigma_{\varepsilon}}\right) \frac{\partial \varepsilon}{\partial x_{j}}\right]+C_{1 \varepsilon} \frac{\varepsilon}{k}\left(P_{\mathrm{k}}+C_{3 \varepsilon} P_{\mathrm{b}}\right)-C_{2 \varepsilon} \rho \frac{\varepsilon^{2}}{k} \\
& +S_{\varepsilon}
\end{aligned}
$$

where, $k$ is the turbulent kinetic energy; $\varepsilon$ is the dissipation; $P_{\mathrm{k}}$ is the generation of turbulence kinetic energy due to the mean 

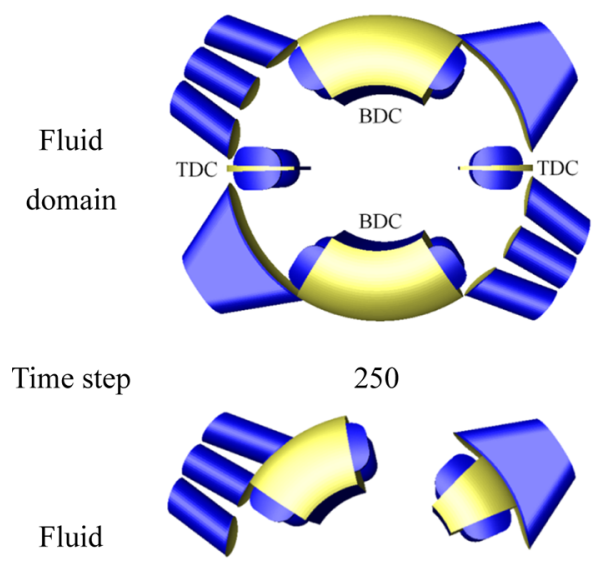

domain

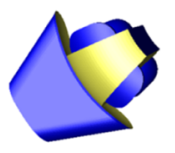

Time step

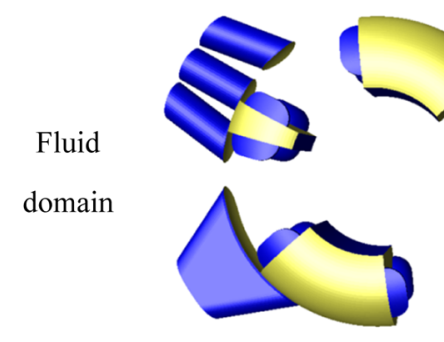

Time step
250
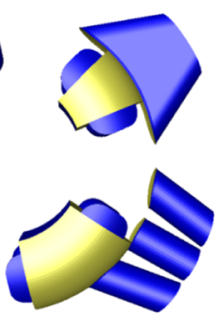

450

620

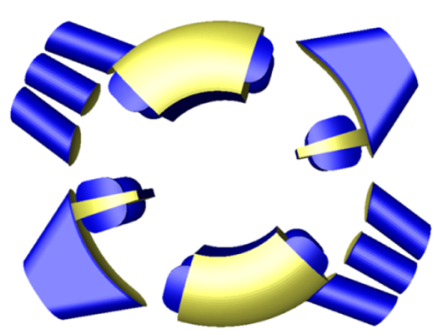

340
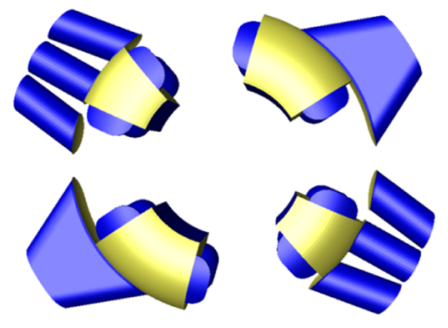

560

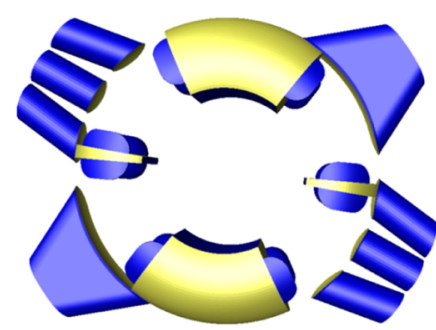

700

Figure 4. Movements of cylinder fluid domains.

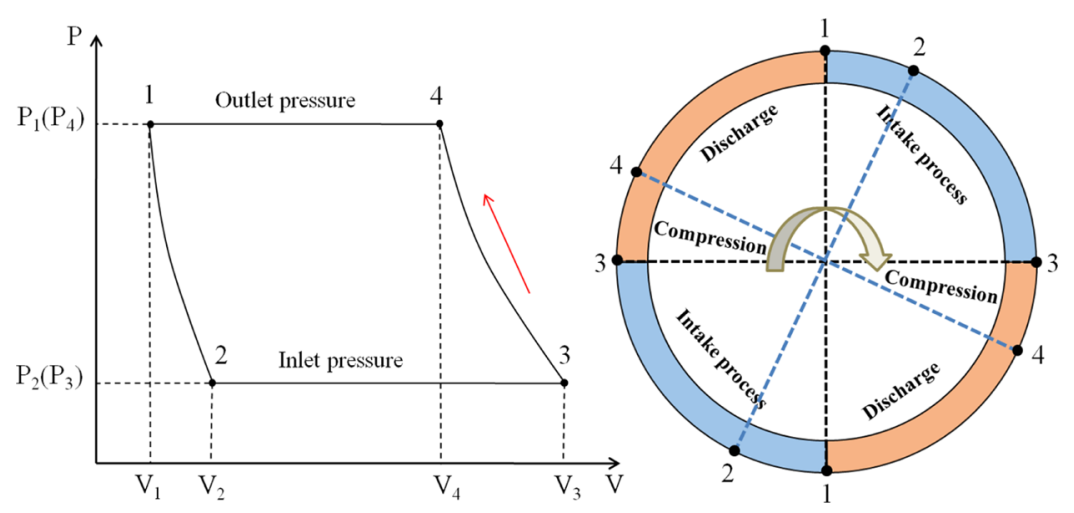

Figure 5. $P-V$ diagram and CA phases.

velocity gradients; $P_{\mathrm{b}}$ is the generation of turbulence kinetic energy due to buoyancy; $Y_{\mathrm{M}}$ is the contribution of the fluctuating dilatation in the compressible turbulence to the overall dissipation rate. $C_{1 \varepsilon}=1.44, C_{2 \varepsilon}=1.92, C_{3 \varepsilon}=-0.33, \sigma_{\mathrm{k}}=1, \sigma_{\varepsilon}$ $=1.3$.

The turbulent viscosity is defined in eq 3

$$
\begin{aligned}
& \mu_{\mathrm{t}}=\rho C_{\mu} \frac{k^{2}}{\varepsilon} \\
& P_{\mathrm{k}}=-\rho \overline{u_{i}^{\prime} u_{j}^{\prime}} \frac{\partial u_{j}}{\partial x_{i}} \\
& P_{\mathrm{k}}=-u_{\mathrm{t}} S^{2}
\end{aligned}
$$

where, $C_{\mu}=0.09, S$ is the modulus of the mean rate-of-strain tensor, it was defined in eq 6

$$
S \equiv \sqrt{2 S_{i j} S_{i j}}
$$

$$
P_{\mathrm{b}} \equiv \beta g_{i} \frac{u_{\mathrm{t}}}{P r_{\mathrm{t}}} \frac{\partial T}{\partial x_{i}}
$$

where, $P r_{\mathrm{t}}$ is the turbulent Prandtl number for energy; $g_{i}$ is the component of the gravitational vector in the $i_{\text {th }}$ direction. Default value of $\operatorname{Pr}_{\mathrm{t}}$ is 0.85 for standard and realizable-models.

The coefficient of thermal expansion, $\beta$, is formulated as eq 8 


$$
\beta \equiv-\frac{1}{\rho}\left(\frac{\partial \rho}{\partial T}\right)_{p}
$$

The governing equation of computational fluid dynamics (CFD) is defined in eq 9

$$
\begin{aligned}
& \frac{\mathrm{d}}{\mathrm{d} t} \int \rho \varnothing \mathrm{d} V+\int \rho \varnothing\left(\vec{u}-\vec{u}_{\mathrm{g}}\right) \mathrm{d} \vec{A} \\
& =\int \Gamma \nabla \varnothing \mathrm{d} \vec{A}+\int S_{\varnothing} \mathrm{d} V
\end{aligned}
$$

where, $\mathrm{d} V$ is the boundary control volume; $\rho$ is the working fluid density; $\vec{u}$ and $\vec{u}_{\mathrm{g}}$ are the flow velocity and the grid velocity of the moving mesh, respectively; $\Gamma$ is diffusion coefficient; $S_{\varnothing}$ is the source term. $^{29}$

2.3. 3D Computational Grid. Dynamic mesh is applied to the unsteady flow calculations in this paper. Table 2 shows the

\section{Table 2. Mesh Number and Overall Mesh Quality}

\begin{tabular}{ll}
\multicolumn{1}{c}{ sub-domains } & \multicolumn{1}{c}{ elements } \\
outlet pipe $1 / 4$ & 12,210 \\
outlet pipe $2 / 5$ & 12,210 \\
outlet pipe $3 / 6$ & 16,632 \\
intake pipe $1 / 2$ & 40,664 \\
cylinder (bowel) & $53,376(37,718)$ \\
minimum orthogonal & 0.337 \\
maximum ortho skew & 0.663 \\
maximum aspect ratio & 16.726
\end{tabular}

mesh number of each fluid subdomain and overall mesh quality. Hexahedral meshes are applied to all of the fluid subdomains in this work. There are two intake pipes, six outlet pipes, and four cylinders (each cylinder has four bowls) in total. Minimum orthogonal, maximum ortho skew, and maximum aspect ratio are $0.337,0.663$, and 16.726 , respectively. It should be noted that the values given in Table 2 are corresponding to values of fluid domains in Figure 3. More settings of the numerical simulation are given in Table 3.

\begin{tabular}{|c|c|c|}
\hline \multicolumn{2}{|c|}{ specifications } & descriptions \\
\hline \multicolumn{2}{|c|}{ pressure-velocity coupling } & simple \\
\hline \multirow[t]{7}{*}{ spatial discretization } & gradient & least squares cell based \\
\hline & pressure & standard \\
\hline & density & second order upwind \\
\hline & momentum & second order upwind \\
\hline & turbulent kinetic energy & first order upwind \\
\hline & turbulent dissipation rate & first order upwind \\
\hline & energy & second order upwind \\
\hline transient formulation & & first order implicit \\
\hline
\end{tabular}

Table 3. Solver Settings in Fluent Software, from the Previous Work $^{31}$

2.4. Stabilities and Convergence of CFD Simulations. Mesh number of the compressor model and converge residuals play an important role in precisions of $3 \mathrm{D}$ simulation results. Stabilities of 3D simulation were investigated under various settings, as listed in Table 4. Maximum difference of average incylinder pressures among the listed scenarios is $12.0 \mathrm{~Pa}$. The results show that mesh numbers and residuals have a limited influence on precisions of simulation results over the given scenarios. Therefore, mesh number 826,128 and residual $10^{-6}$ were used for $3 \mathrm{D}$ simulations in this work. Simulations are
Table 4. Simulation Results Among Different Scenarios

$\begin{array}{clc}\text { mesh number } & \text { residuals } & \text { average in-cylinder pressure/Pa } \\ 640,048 & 10^{-6} & 99,591 \\ & 5 \times 10^{-6} & 99,597 \\ 826,128 & 10^{-6} & 99,599 \\ & 0.3 \times 10^{-6} & 99,594 \\ 149,474 & 10^{-6} & 99,587\end{array}$

considered to be converged when residuals are smaller than $10^{-6}$ during calculations. It should be noted that average in-cylinder pressures shown in the table are the values at the end of the intake process.

2.5. Boundary Conditions of 3D Simulations. As seen from Figure 1, the ORP compressor has six outlet pipes locating at different positions. It provides a possibility of different pressure output, without modifying layouts of inlet and outlet pipes. Table 5 gives boundary conditions of different simulation

Table 5. Boundary Conditions for CFD Simulations

\begin{tabular}{lcccc}
$\begin{array}{c}\text { boundary conditions } \\
\text { inlets } 1 \text { and 2 } \\
\text { pressure/bar }\end{array}$ & scenario 1 & scenario 2 & scenario 3 & scenario 4 \\
$\begin{array}{c}\text { inlets } 1 \text { and 2 } \\
\text { temperature/K }\end{array}$ & 1.0 & 1.0 & 1.0 & 1.0 \\
$\begin{array}{c}\text { outlets } 1 \text { and } 4 \\
\text { pressure/bar }\end{array}$ & 1.1 & blocked & blocked & $\begin{array}{c}\text { pressure } \\
\text { profile }\end{array}$ \\
$\begin{array}{c}\text { outlets } 2 \text { and 5 } \\
\text { pressure/bar }\end{array}$ & 1.1 & blocked & 1.7 & 1.7 \\
$\begin{array}{c}\text { outlets } 3 \text { and 6 } \\
\text { pressure/bar } \\
\text { rotation speed/rpm }\end{array}$ & 1.1 & 2 & 1.7 & 1.7 \\
working fluid & 3000 & 3000 & 3000 & 3000 \\
\hline
\end{tabular}

scenarios. Seen from Figure 4, outlet pressure will be low if outlet ports 1 and 4 open as long as pistons pass them. This situation will be explored in scenario 1 . It should be noted that the pressure profile in scenario 4 was extracted from results of scenario 3 to make the outlets 1 and 4 blocked when the incylinder pressure is lower than 1.7 bar.

\section{RESULTS AND DISCUSSION}

PEM fuel cell systems are free of emissions and have a high energy density, which is good for automotive applications. Adoptions of PEM fuel cell systems promote cleaner productions of automotive companies and sustainability of personal utilization. Fuel cell systems have different requirements for compressors compared to conventional ones, for example, compressors in vehicle turbochargers. Compressor performance significantly influences the efficiency of PEM fuel cell systems. Excellent compressor accelerates the applications of PEM fuel cell systems to automotive.

Cylinder volume changes of the ORP compressor are in sinusoidal mode, as shown in Figure 6. Variations of cylinder volumes 1 and 3 are the same, their operation processes are synchronous. Cyclic period of the ORP compressor is $180^{\circ} \mathrm{CA}$, resulting of compressor mass flow rates being twice of reciprocating piston compressors in theory under the same boundary conditions. This fact conduces to decrease compressor size. There is no doubt that the ORP compressor can provide a high pressure air, meeting the requirements of fuel cell systems. However, mass flow rates and energy consumption are still unknown. In this section, mass flow rates and energy consumptions will be explored. 


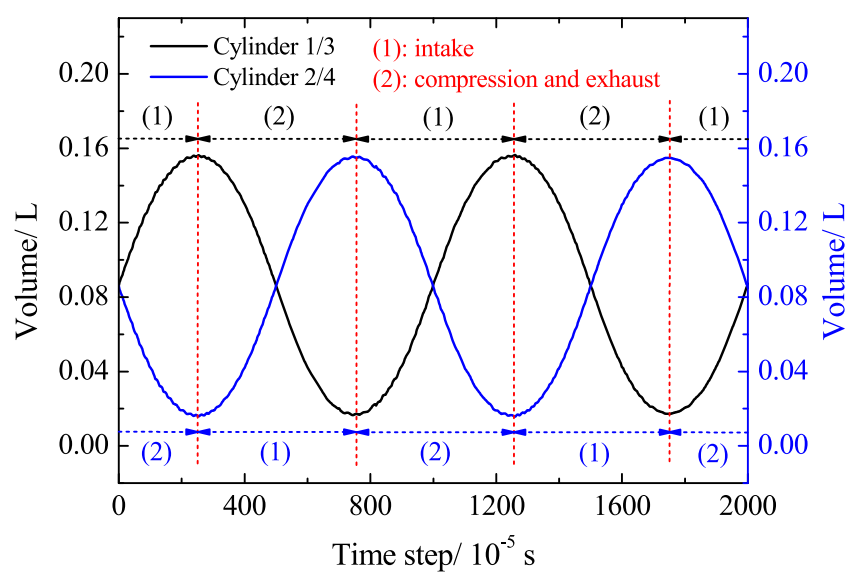

Figure 6. Cylinder volume variations in two cyclic periods.

3.1. ORP Compressor Operating under Scenarios 1 and 2. As indicated in Table 3, a low outlet pressure (1.1 bar) is set in scenario 1 ; pressure of outlet 3 is set as 2.0 bar in scenario 2 , where outlets 1 and 2 are blocked. Preliminary explorations will be done using these two scenarios first. The cyclic period of the ORP compressor is half of reciprocating piston compressors, resulting of less heat loss in each cycle. Therefore, it conduces to increase the compressor efficiency from this point. Additionally, friction losses will be different from other compressors because of the particular structures. As indicated by the work ${ }^{32}$ that compressor structures had a significant impact on friction losses, it was demonstrated by the data that total friction losses in swing vane compressors were only $35.87 \%$ of those in a sliding vane compressor, when the rotation speed was $1000 \mathrm{rpm}$; the value reached $68.96 \%$ when the compressor rotation speed increased to $3000 \mathrm{rpm}$. Yanagisawa ${ }^{33}$ also investigated friction losses in a rolling piston-type compressor using a mathematical model, indicating that a short "length/diameter" piston contributed to decreasing friction losses, but it decreased the reliability of the compressor. As the "stroke" of the ORP compressor is longer than that of conventional piston compressors, leading to higher friction losses. The "stroke" used for the friction loss calculations should be the distance that the pistons go through rather than the geometrical stroke.

3.1.1. In-Cylinder Pressure Analysis. In-cylinder pressure evolutions significantly affect compressor efficiency, energy consumption, and mass flow rates. In this part, in-cylinder pressures over scenario 1 were analyzed, as shown in Figure 7. Explanations of the dots marked in pressure profiles are listed in Table 6, which is also applied to following figures. Outlet and inlet valve timing (opening and closing) is marked by the dots, which are helpful to understand the pressure changes during compressor operation. Pressure profiles of cylinders 1 and 3 are the same; and they are the same for cylinders 2 and 4 . In the discharge stroke, in-cylinder pressures show multipeaks, with the pressure increasing at the beginning, followed by a decrease. Incylinder pressure increase is caused by a rapid change of cylinder volume despite the opening of outlet port 1 increases gradually (after dot 1). The pressure decrease after the first peak is caused by the opening of outlet port 2 , resulting of the in-cylinder pressure being approximately equal to the outlet pressure (1.1 bar, before dot 3 ). Then, the pressure increases significantly caused by the closing of outlet port 1 (after dot 3 ). The opening of outlet port 3 presents a small impact on the in-cylinder pressure. After the closing of outlet port 2, the in-cylinder

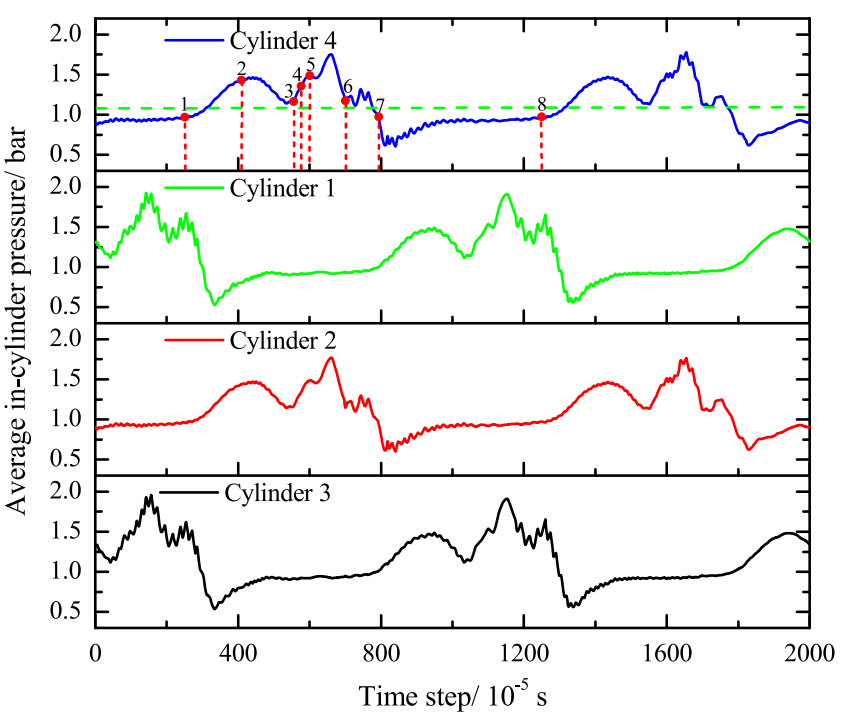

Figure 7. Average in-cylinder pressure over scenario 1.

Table 6. Explanations of Dots Marked in Pressure Profiles

\begin{tabular}{cl} 
dot number & \multicolumn{1}{c}{ explanations } \\
1 & outlet 1 starts to open \\
2 & outlet 2 starts to open \\
3 & outlet 1 completely closed \\
4 & outlet 3 starts to open \\
5 & outlet 2 completely closed \\
6 & outlet 3 completely closed \\
7 & inlet 1 starts to open \\
8 & inlet 1 completely closed
\end{tabular}

pressure reaches maximum value in a short time. At the end of the discharge process, there is a slight increase in pressure because of the residual air in cylinders and slight earlier closing of outlet port. The maximum in-cylinder pressure during discharge is approximately 1.8 bar, being much higher than the outlet pressure because of a short cyclic period in time. In the intake process, the in-cylinder pressure reaches a constant value in a small CA. The minimum in-cylinder pressure is approximately 0.6 bar. The in-cylinder pressure is joint results of cylinder volume changes and mass flow from inlet and outlets.

In scenario 2 , outlets 1 and 2 are blocked. In-cylinder pressures over scenario 2 are shown in Figure 8. It should be noted that the maximum in-cylinder pressure reaches 10 bar when outlet port 3 starts to open. It indicates that the compressor can provide super high pressure air. In this scenario, the in-cylinder pressure is much higher than outlet pressure, which will lead to a high energy loss. The in-cylinder pressure still increases after dot 4, resulting from a small effective outlet port area. The in-cylinder pressure is approximately 5.0 bar at the end of the discharging process because of a short discharging duration in time step. Additionally, the in-cylinder pressure profile will be used to define the boundary pressure of outlet 1 for scenario 4. As for the ORP compressor, a higher outlet pressure would cause a lower mass flow rate, meeting the requirements of air supply for PEM fuel cell systems. However, the three outlets should be jointly used to decrease the incylinder pressure in the discharging process to ensure low energy consumption. Maximum in-cylinder pressure of a reciprocating piston compressor was approximately 9.1 and 5.9 bar for outlet pressure of 7.86 and 4.71 bar, respectively. ${ }^{34}$ Judged from the in- 


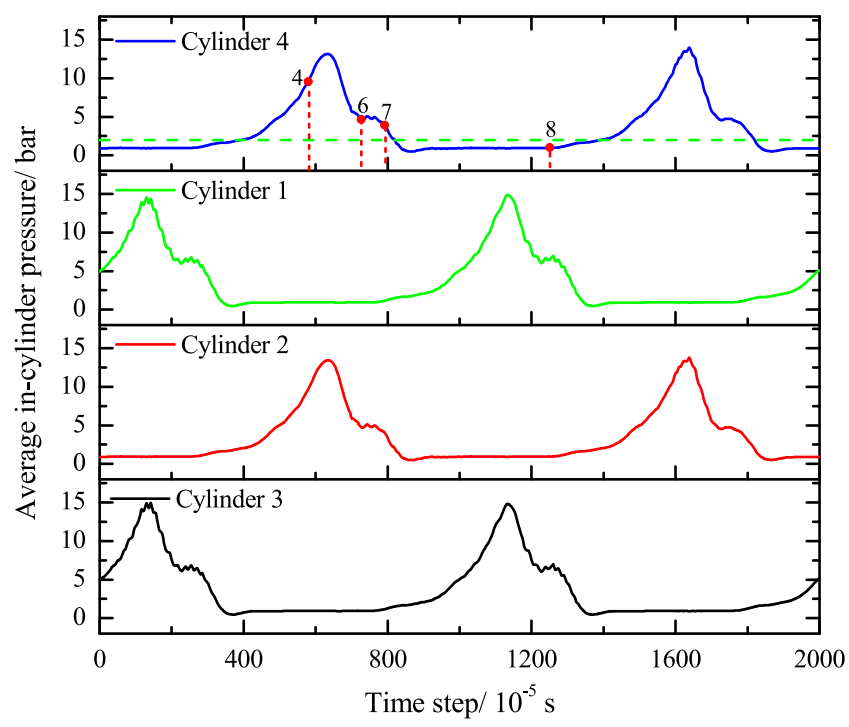

Figure 8. Average in-cylinder pressure over scenario 2.

cylinder pressure evolutions, the authors' ORP compressor under these two cases has a higher energy consumption and lower efficiency than the reciprocating compressor. ${ }^{34}$ In this work, ${ }^{34}$ the swept volume was $0.5792 \mathrm{~L}$, with a clearance factor being $4.5 \%$. Compressor rotation speed was approximately 940 rpm, which partly contributed to lower energy losses compared to the authors' work. In-cylinder pressure evolutions provide the evidence of improving the inlet and outlet pipe structures, to achieve a higher efficiency and lower energy consumption, resulting of a cleaner production of vehicle markets. In-cylinder temperature evolutions over various scenarios of this ORP compressor are shown in the Supporting Information (Figures S1, S3, S5, and S7).

3.1.2. Mass Flow Rate Analysis. Inlet and outlet mass flow rates of this ORP compressor over scenario 1 are shown in Figure 9. It should be noted that there is a slight backflow in outlet 1 at the beginning of discharging. It should be avoided for the application in PEM fuel cell systems. Maximum mass flow rate of outlet 1 is approximately $0.12 \mathrm{~kg} / \mathrm{s}$, and it is $0.08 \mathrm{~kg} / \mathrm{s}$ for both outlets 2 and 3 . Outlet 1 dominates the mass flow of the cylinders compared to the other two. The mass flow of outlet 3 is

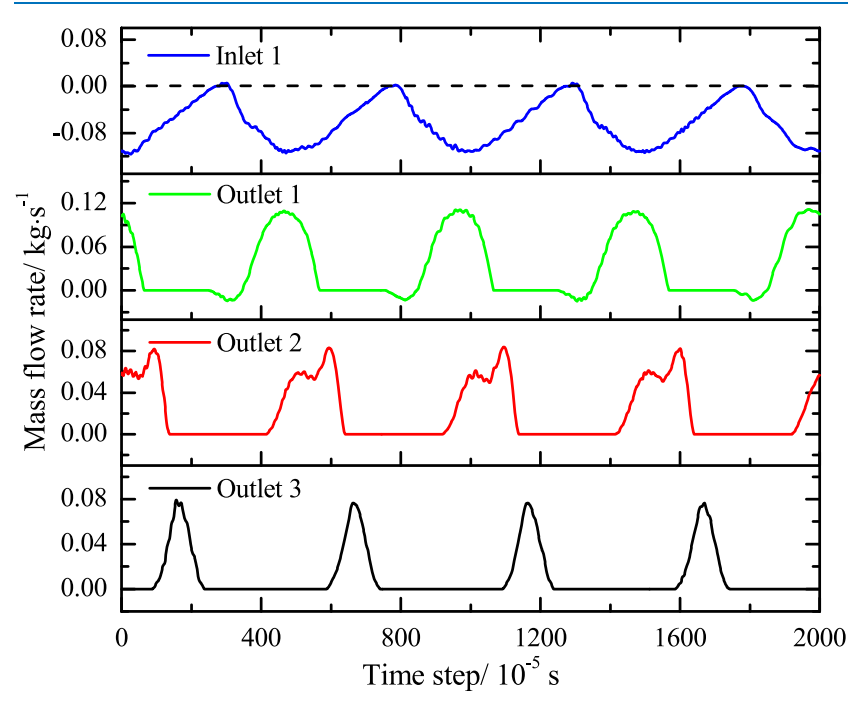

Figure 9. Inlet and outlet mass flow rates over scenario 1, system 1 . low, which is caused by short operation duration in time and a small effective outlet area when cylinders pass the outlet. Maximum inlet mass flow rate of inlets is approximately $0.12 \mathrm{~kg} /$ $\mathrm{s}$, and the inlets work almost continuously. Leakages in this work are neglected, but it has a significant effect on the efficiency. As demonstrated by Shen et al. ${ }^{35}$ using a mathematical model, volumetric efficiency decrease was in the range of $4.42-7.7 \%$ when the fitting clearance height of a centrifugal compressor increased from 0.03 to $0.09 \mathrm{~mm}$. Also, a maximum drop of fuel cell system power output caused by leakages was approximately $20 \%$ under $3000 \mathrm{rpm} .{ }^{17}$ It implies that the efficiency of this ORP compressor, obtained using this $3 \mathrm{D}$ numerical simulation approach, will be slightly overestimated. Sealing should be considered when designing the ORP compressor to increase the overall efficiency of the PEM fuel cell system.

Mass flow rates of air exchange system 1 over scenario 2 are shown in Figure 10. It is significantly different from scenario 1

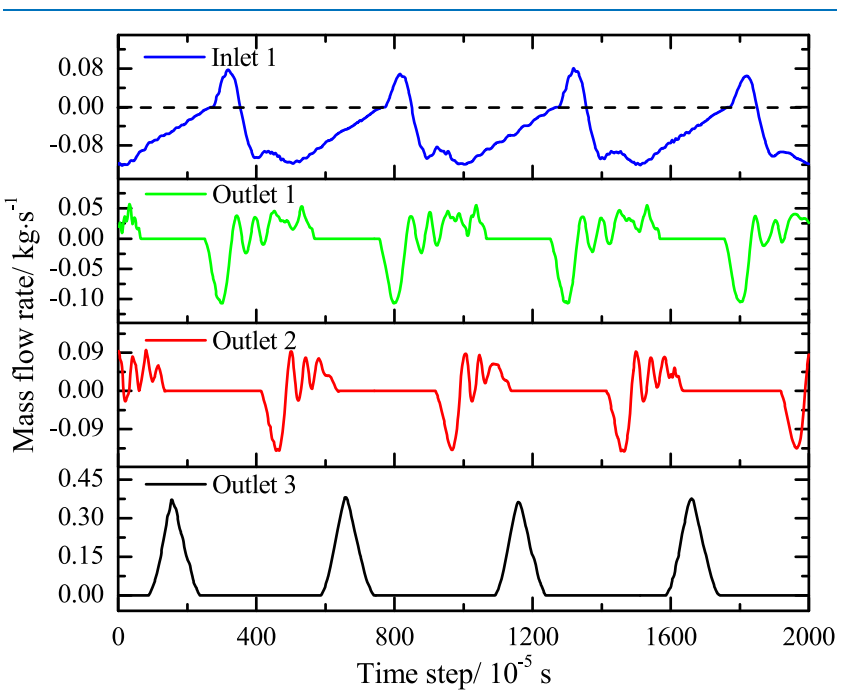

Figure 10. Inlet and outlet mass flow rates over scenario 2, system 1 .

because of in-cylinder pressure characteristics. Mass flow rates of air exchange system 2 are almost the same as system 1 , as shown in Figure S2. There is a strong backflow at the start of the intake process, resulting from high pressure residual air in the cylinders. The backflow will cause extra energy loss despite the impact is small. The air in the first two outlet pipes (outlets 1 and 2) are back and forth, caused. However, net mass flow of the two outlet pipes is zero because the outlets are blocked. Maximum mass flow rate from outlet 3 reaches $0.37 \mathrm{~kg} / \mathrm{s}$. The mass flow rate of a centrifugal compressor designed by Qi et al. ${ }^{15}$ was in the range of $0.022-0.068 \mathrm{~kg} / \mathrm{s}$, additionally, the compressor efficiency increased with rotation speeds. It has a similar size to the authors' ORP compressor. The mass flow rate is smaller than the authors' compressor, and the range is seriously limited by surge phenomenon. Higher mass flow rate contributes to compressor downsize, further promotes the applications of PEM fuel cell systems to automotive, resulting in a clean production with less fuel consumption and emissions.

3.1.3. P-V Diagram Analysis. Compressor used for PEM fuel cell system applications should be low energy consumption, which can be indirectly judged by $P-V$ diagrams. Figures 11 and 12 show $P-V$ diagrams over scenario $1 . P-V$ diagrams of two cycles in one rotation are almost overlapped. In the discharging process, majorities of the compressor operation points are in statuses of a much higher in-cylinder pressure than that of 


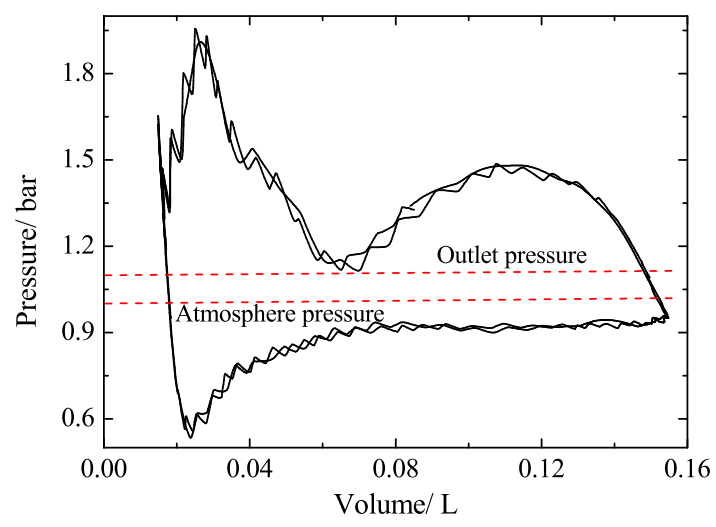

Figure 11. $P-V$ diagram of cylinder 1 over scenario 1 .

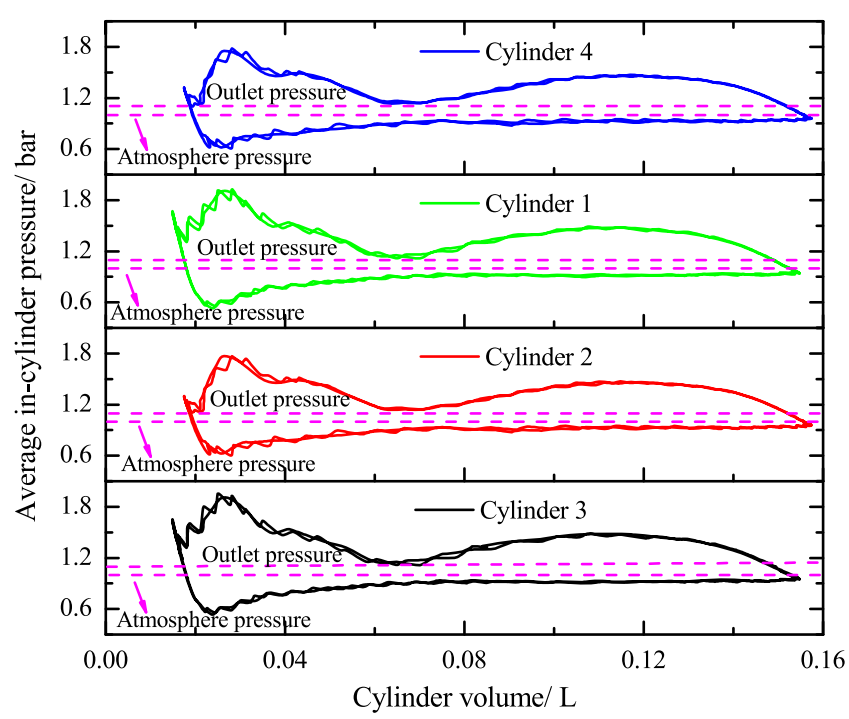

Figure 12. $P-V$ diagrams of four cylinders over scenario 1 .

outlets, which significantly increases the energy consumption. However, the average mass flow rate of the ORP compressor is twice of conventional reciprocating compressors in theory such that energy utilizations need to be further discussed considering energy consumption and mass flow rates (Section 4). Pressure increase at the end of discharging process has a limited impact on energy consumption because of a small change of cylinder volume. As for scenario 2 , area covered by $P-V$ lines is much bigger than that of scenario 1, which means higher energy consumption in scenario 2, as shown in Figures 13 and 14. It was demonstrated by the work ${ }^{36}$ that power output of fuel cell systems increased with the compressor pressure ratio, but it led to high energy consumption of air compressors. Theoretically, maximum energy utilization efficiency happens when $n$-cylinder pressure in the discharge process is the same as outlet pressure. The strategy of outlet valve timing in scenario 2 is suitable for a super high pressure situation to ensure high compressor efficiency. Stouffs et al. ${ }^{34}$ investigated performances of a reciprocating piston compressor, whose in-cylinder pressure still increased rapidly after it reached the outlet pressure. In addition, the in-cylinder pressure at the end of discharging process is much higher than the outlet pressure, leading to a higher energy consumption and lower mass flow rate.

3.2. ORP Compressor Operating under Scenarios 3. Based on the analysis of scenarios 1 and 2, outlets 1 and 2 should

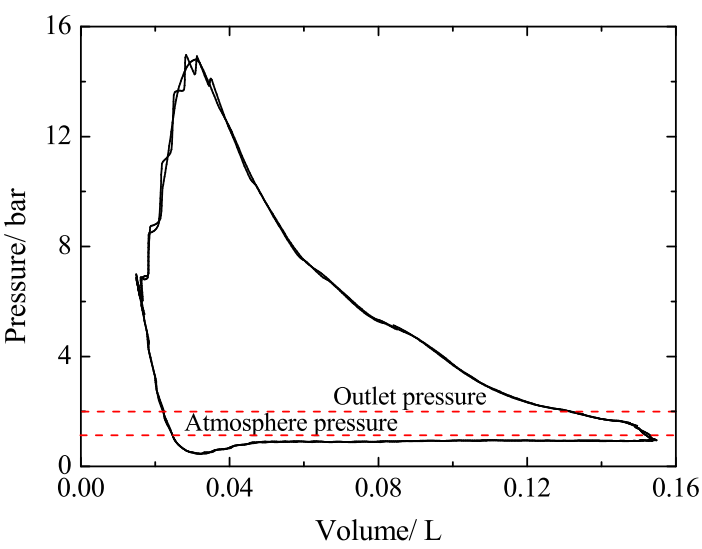

Figure 13. $P-V$ diagram of cylinder 1 over scenario 2 .

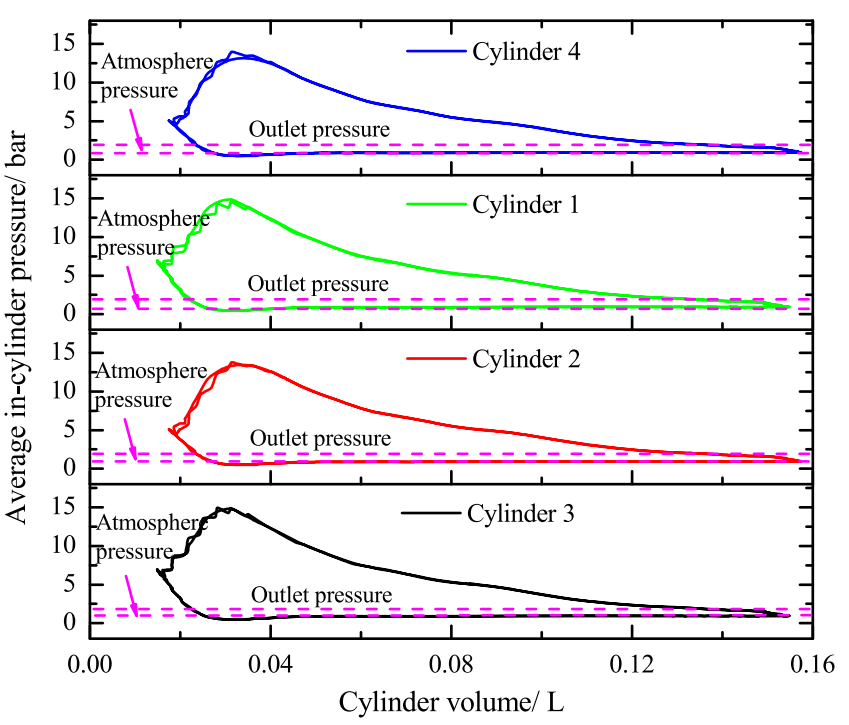

Figure 14. $P-V$ diagrams of four cylinders over scenario 2 .

not be blocked to ensure high compressor efficiency. In this section, scenario 3 is investigated.

3.2.1. In-Cylinder Pressure Analysis. The in-cylinder pressure of the ORP compressor over scenario 3 is shown in Figure 15. Pressures during the discharging process have multipeaks, resulting from the joint actions of in-cylinder pressure evolutions and mass flow rates. The maximum incylinder pressure is lower than 2.8 bar, which is still higher than the outlet pressure ( $1.7 \mathrm{bar})$. The outlet pressure in scenario 3 is at a higher level than other types of compressors applied to PEM fuel cell systems. ${ }^{37,38}$ Higher outlet pressure could lead to a lower volumetric efficiency and higher energy consumption. As indicated in the work, ${ }^{34}$ volumetric efficiency of a compressor decreased from 66.7 to $51.0 \%$ when the outlet pressure increased from 3.0 to 10 bar. In addition, specific work increased from 210 to $490 \mathrm{~kJ} / \mathrm{kg}$; and the specific work almost linearly increased with outlet pressure. A small difference between outlet pressure and in-cylinder pressure contributes to high efficiency, which is the main point of the authors' future work to improve the compressor efficiency.

3.2.2. Mass Flow Rate Analysis. Mass flow rates of an inlet and three outlets of the compressor are shown in Figure 16. A weak backflow happens in the intake process, the maximum flow rate is approximately $0.115 \mathrm{~kg} / \mathrm{s}$. Peak values of mass flow rates are approximately 0.2 and $0.09 \mathrm{~kg} / \mathrm{s}$, respectively, for outlets 2 


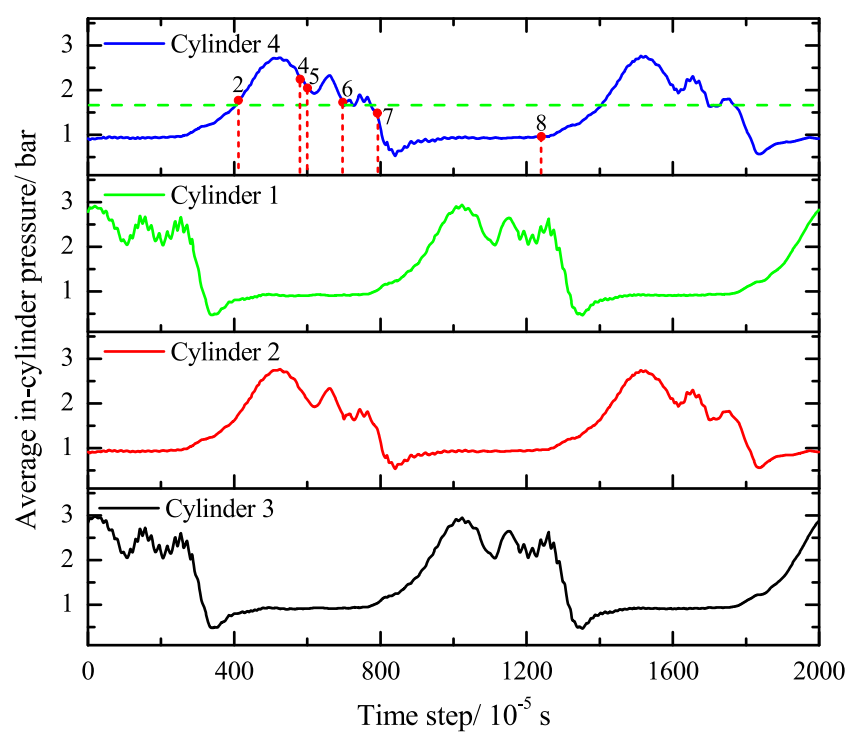

Figure 15. Average in-cylinder pressure over scenario 3.

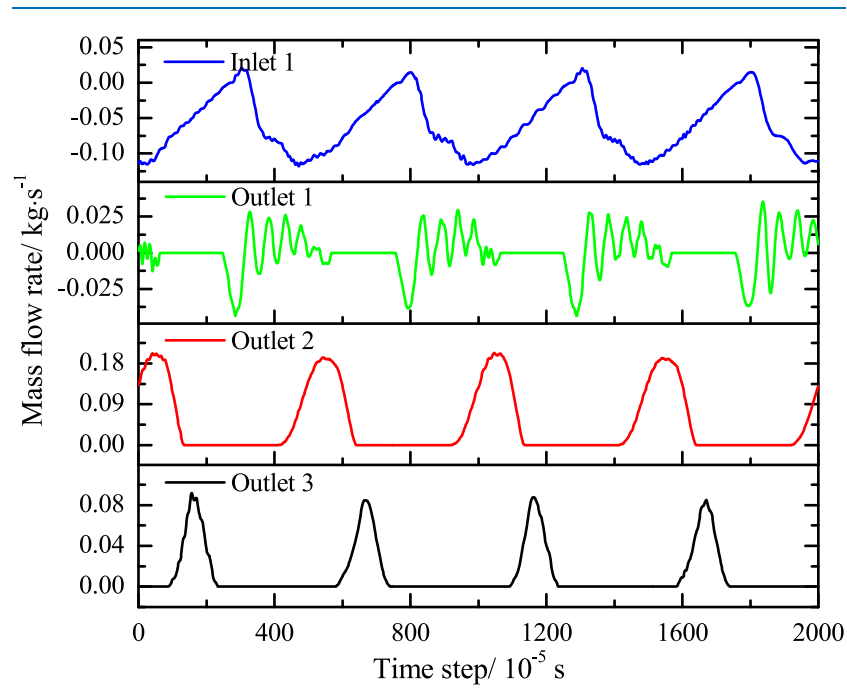

Figure 16. Inlet and outlet mass flow rates over scenario 3, system 1.

and 3. Outlet 2 dominates the mass flow of the ORP compressor over scenario 3 . The mass flow is not continuous, such that the air supply is interrupted in one-third durations of the discharging process. Additionally, the mass flow fluctuations are serious, which is different from centrifugal compressors where the mass flow rate changes slightly under a given operating condition. ${ }^{39}$

3.2.3. P-V Diagram Analysis. $P-V$ diagrams of the ORP compressor over scenario 3 are shown in Figures 17 and 18. At the first half of the discharging process, in-cylinder pressure almost increases to 3.0 bar, which implies spaces of decreasing energy consumption by dropping the in-cylinder pressure. Incylinder temperature evolutions during the compressor operating are shown in the "Supporting Information" for all scenarios. As mentioned above, outlet port 3 closes slightly before TDC, which leads to an increase of in-cylinder pressure. However, the corresponding energy loss is low because of small changes in volume at the end of the discharging process. $P-V$ diagrams were also used by $\mathrm{He}$ et al. ${ }^{16}$ to investigate the effects of rotation speed and discharging pressure on a twin-screw air compressor performance. The results indicated that the volumetric efficiency and isentropic efficiency of the compressor

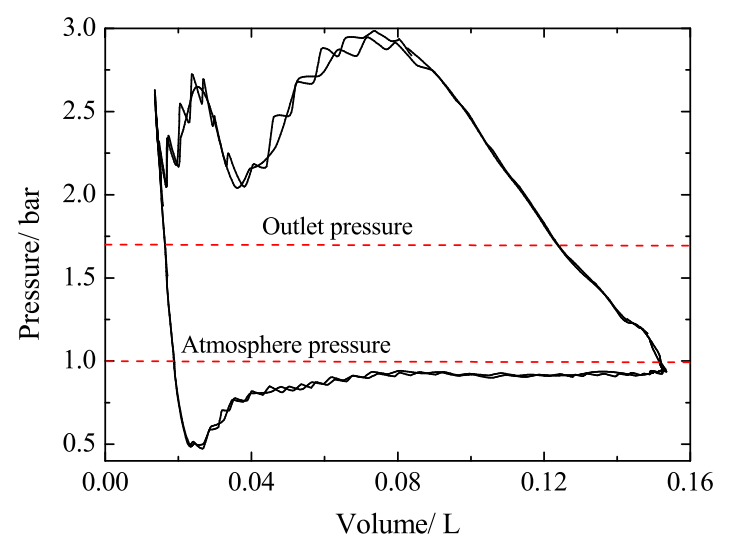

Figure 17. $P-V$ diagram of cylinder 1 over scenario 3 .

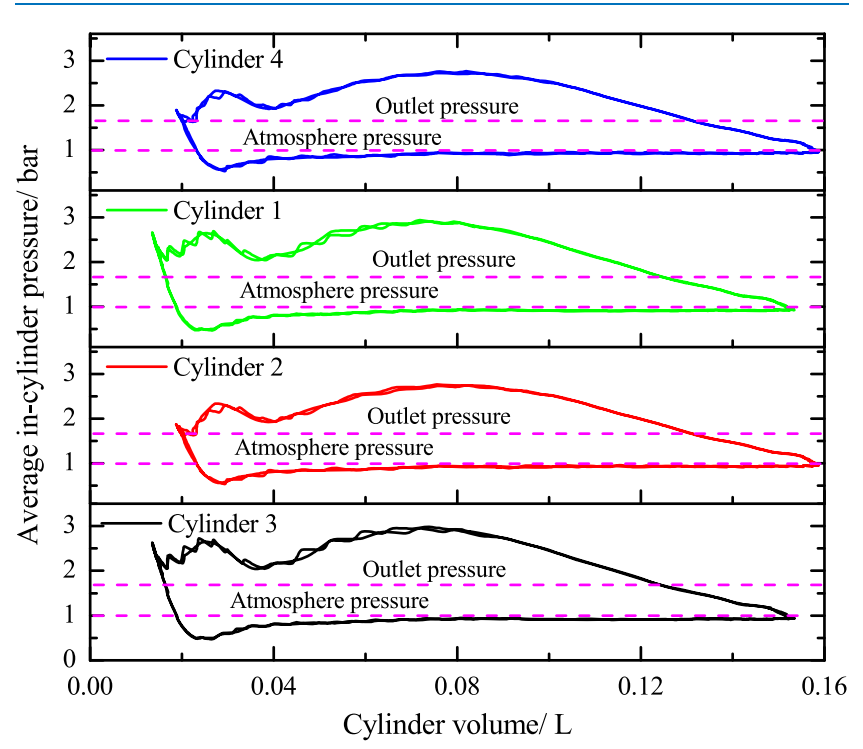

Figure 18. $P-V$ diagrams of four cylinders over scenario 3.

were 70 and $55 \%$ over discharging pressure of 2.0 bar and female rotor speed of $9000 \mathrm{rpm}$. The rotation speed is much higher than piston compressors; the mass flow rate of screw compressors is much lower than that of piston compressors under the same rotation speed.

3.3. OPR Compressor Operating under Scenario 4. It can effectively decrease the in-cylinder pressure in a short time if outlet port 1 opens as long as the in-cylinder pressure reaches the target pressure. Scenario 4 will explore the situation.

3.3.1. In-Cylinder Pressure Analysis. Average in-cylinder pressure over scenario 4 is shown in Figure 19. Overall incylinder pressure is lower than that of scenario 3. Maximum incylinder pressure is approximately 2.5 bar, resulting of a decreased energy consumption compared to other scenarios, which benefits from the intake port 1 . In-cylinder pressure profile is similar to scenario 3 after inlet port 2 closes. Koh ${ }^{40}$ analyzed the characteristics of a linear compressor whose stroke decreased with frequency, resulting of a significantly drop of the mass flow rate. In addition, natural frequency of the linear compressor and amplitude of pressure wave increased as charging pressures. Barth ${ }^{41}$ researched a free piston compressor whose efficiency decreased from 65 to $25 \%$ when the pressure ratio increased from 2.0 to 15.0 . Also, the efficiency decrease was sharp when the pressure ratio was lower than 3.0. 


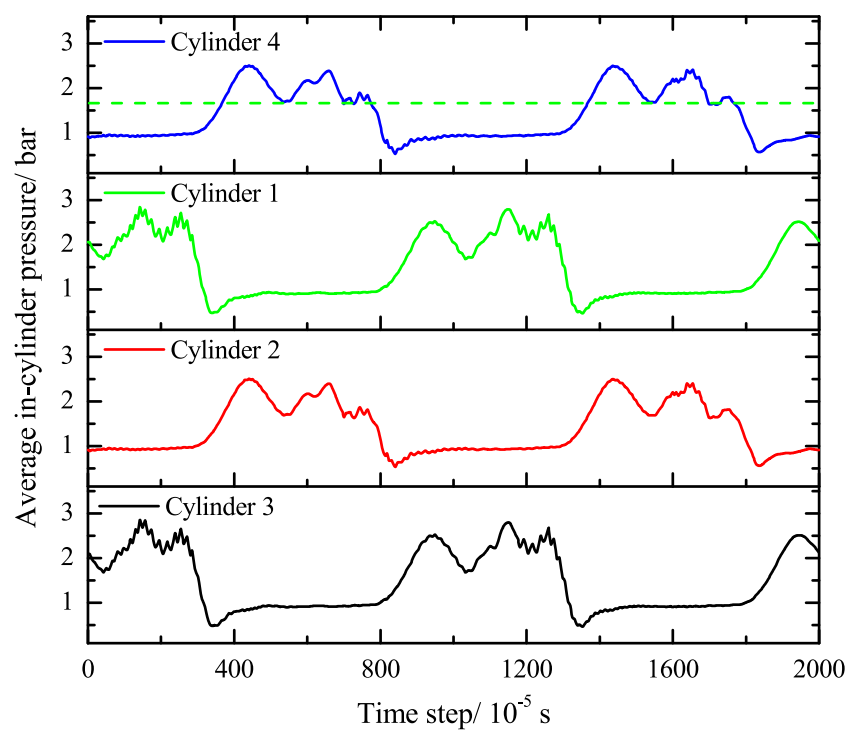

Figure 19. Average in-cylinder pressures over scenario 4.

3.3.2. Mass Flow Rate Analysis. In scenario 4, the pressure of outlet 1 is set as a variable. It changes with time to ensure that there is not any air flow between the atmosphere and inlet ports if the in-cylinder pressure is lower than 1.7 bar. Mass flow rate profiles for outlets 1 and 2 in this case are different from those of scenario 3 where the contribution of outlet 1 to the total mass flow is zero. At the start of the compression process, part of the air flows into the cylinders from outlet pipe 1, as shown in Figure 20. As long as the in-cylinder pressure is higher than $1.7 \mathrm{bar}$, the

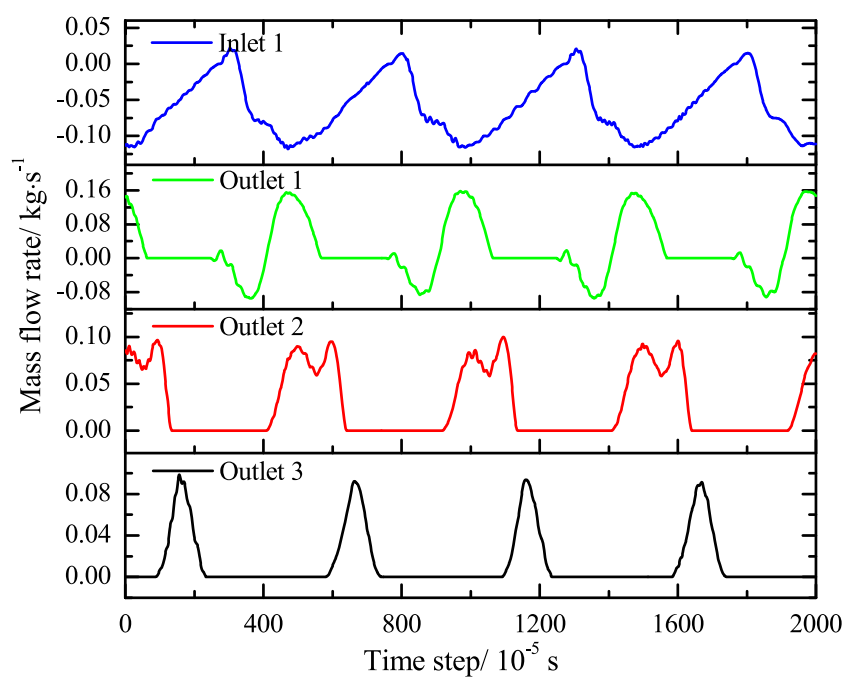

Figure 20. Inlet and outlet mass flow rates over scenario 4, system 1.

mass flow rate of outlet 1 increases significantly, with the maximum value reaching $0.16 \mathrm{~kg} / \mathrm{s}$. Mass flow rate of outlet port 2 shows double peaks, with the maximum value being less than $0.1 \mathrm{~kg} / \mathrm{s}$, which is much lower than that in scenario 3 .

3.3.3. $P-V$ Diagram Analysis. $P-V$ diagrams of the compressor in scenario 4 are shown in Figures 21 and 22. The energy consumption for this scenario is almost twice of the ideal conditions, which can be estimated from the area covered by the $P-V$ lines. High energy consumption is mainly caused by the high in-cylinder pressure during discharging. A low compressor rotation speed (less than $500 \mathrm{rpm}$ ) effectively decreased the

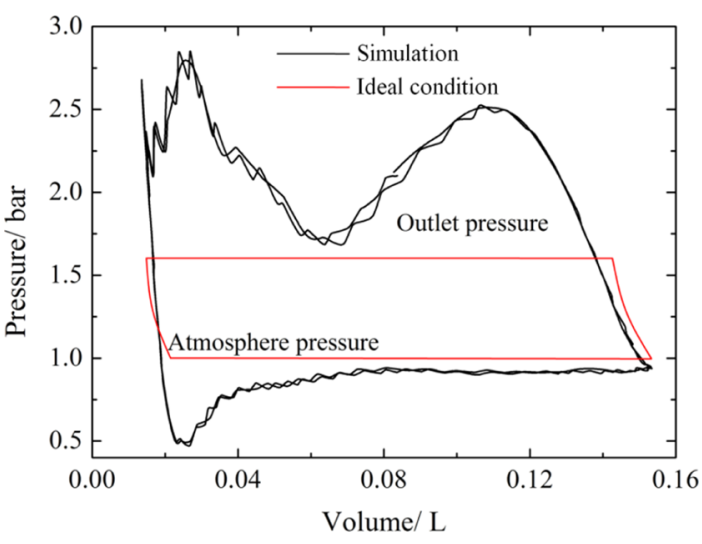

Figure 21. $P-V$ diagram of cylinder 1 over scenario 4 .

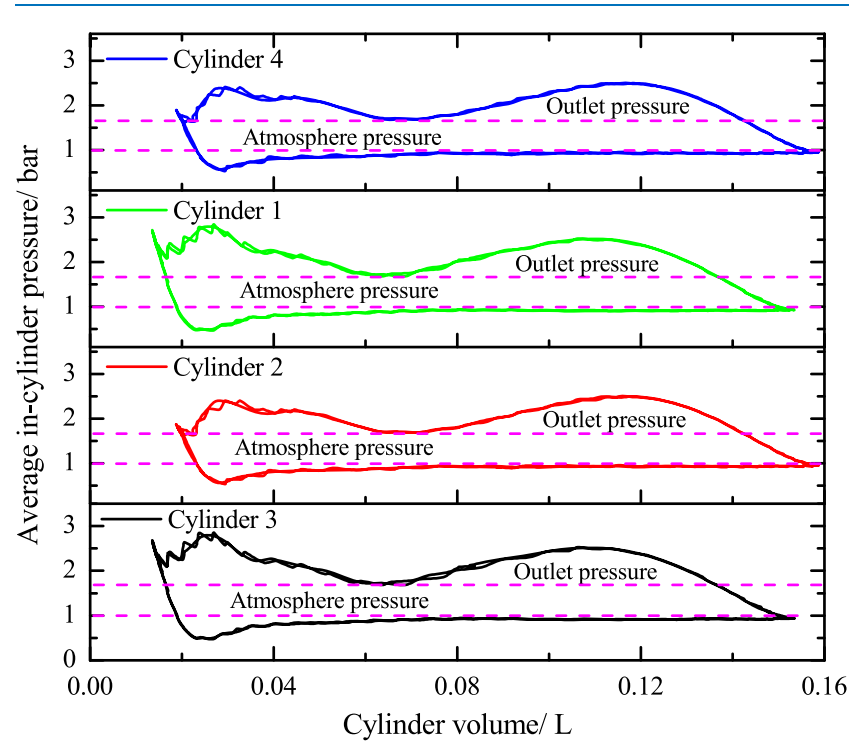

Figure 22. $P-V$ diagrams of four cylinders over scenario 4 .

energy consumption, as presented by Elhaj et al., ${ }^{42}$ resulting of the in-cylinder pressure being very close to the outlet pressure. In order to decrease the in-cylinder pressure in the discharging process, rotation speed should be decreased to achieve a long discharging duration. Lower rotation speed effectively decreased the pressure losses, as demonstrated by Mi et al. ${ }^{20}$ using $P-V$ diagrams. However, lower rotation speed will lead to a smaller mass flow rate under the same boundary conditions, which will significantly prevent downsize. Additionally, lower speed led to serious vibrations, resulting of a shorter life time of compressors. ${ }^{20}$ Because of the application of the compressor to PEM fuel cell systems, the compressor should be as compact as possible. In the future work, a balance between energy consumption and the compressor size will be done to achieve an excellent overall performance. In addition, the outlet structures can be optimized to decrease energy consumption by replacing outlets 1 and 2 using a bigger outlet, and the new outlet will be positioned close to outlet 3 .

3.3.4. Streamlines in the Compressor. In this paper, the authors only present the streamlines in the compressor over scenario 4, as shown in Figure 23. As indicated in the figure, air flows out of the cylinders through outlets 1 and 2 when the leading faces of the cylinder pass outlet port 1 . The air velocity increases up to $180 \mathrm{~m} / \mathrm{s}$ when leading faces of the cylinders arrive at the middle position of outlet port 2. It results of a 


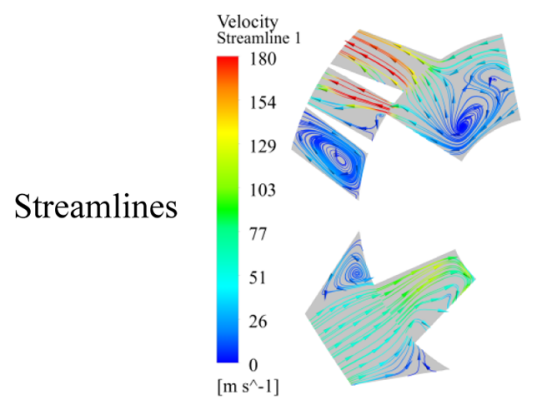

Time step

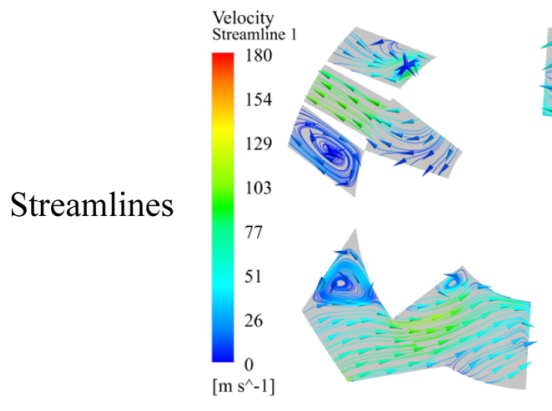

Time step

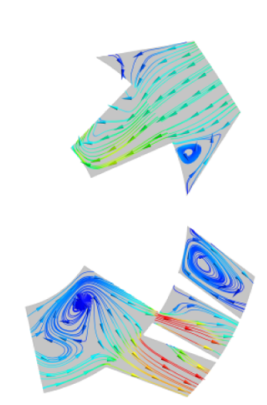

450

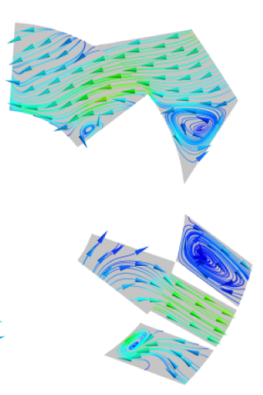

580
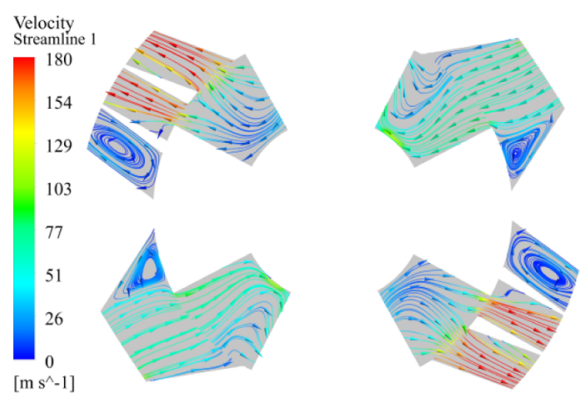

560
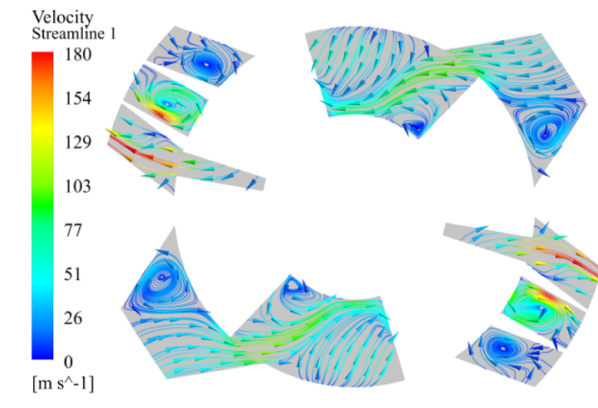

660

Figure 23. Streamlines of fluid in the compressor as time steps.

sudden decease of the in-cylinder pressure. Then, the fluid velocity drops to lower than $80 \mathrm{~m} / \mathrm{s}$. Further, the velocity increases to more than $100 \mathrm{~m} / \mathrm{s}$ because of a small effective area of outlet port 3. Fluid flow has been widely investigated for centrifugal compressors, and the most important issue is surge phenomenon, which will not happened in this ORP compressor. Zhang et al. ${ }^{43}$ analyzed a centrifugal compressor of the PEM fuel cell system using a simulation model developed by coupling AMESim with MATLAB/Simulink codes. The simulation was conducted under New European Driving Cycle, indicating that the centrifugal compressor operated at a narrow area near the surge line. An adaptive controller was used to drive compressors to operate at a target zone to avoid operating in the surge zone. ${ }^{44}$ However, it is still difficult for centrifugal compressors to provide a low mass flow rate under high pressure.

\section{ENERGY CONSUMPTION AND ADIABATIC EFFICIENCY}

Important parameters used to evaluate the compressor performance are energy consumption, average mass flow rate, and adiabatic efficiency, as given in Table 7. Scenario 1 has the smallest energy consumption and the highest mass flow rate; however, the outlet pressure is too low to meet the requirements

Table 7. Performance of the ORP Compressor Over Four Scenarios

\begin{tabular}{|c|c|c|c|c|}
\hline & scenario 1 & scenario 2 & scenario 3 & scenario 4 \\
\hline outlet pressure & $1.1 \mathrm{bar}$ & $2.0 \mathrm{bar}$ & $1.7 \mathrm{bar}$ & 1.7 bar \\
\hline $\begin{array}{l}\text { energy consumption } \\
\text { rate } / \mathrm{kW}\end{array}$ & 2.83 & 27.39 & 7.56 & 6.62 \\
\hline mass flow rate $/ \mathrm{kg} \cdot \mathrm{s}^{-1}$ & 0.062 & 0.052 & 0.059 & 0.059 \\
\hline $\begin{array}{l}\text { specific mass flow } \\
\text { rate } / \mathrm{kg} \cdot(\mathrm{s} \cdot \mathrm{L})^{-1}\end{array}$ & 0.113 & 0.094 & 0.108 & 0.108 \\
\hline adiabatic efficiency $/ \%$ & 18.05 & 12.41 & 38.52 & 43.96 \\
\hline specific work $/ \mathrm{kJ} \cdot \mathrm{kg}^{-1}$ & 45.64 & 526.73 & 128.14 & 112.20 \\
\hline
\end{tabular}

of the PEM fuel cell system. Scenarios 3 and 4 are suitable for the air supply of PEM fuel cell systems from the viewpoint of the mass flow rate and pressure ratio; however, the energy consumption should be further dropped by decreasing incylinder pressure during discharge. The outlet pressure does not have a significant effect on the mass flow rate, with the maximum difference being less than $4.06 \%$ among the given scenarios. The mass flow rates of scenarios 3 and 4 are the same, but the energy consumption is different because of the in-cylinder pressure. In this paper, energy consumption calculations only consider the heat loss in the operating process. In fact, other factor, for example, friction loss will cause extra energy consumption. Park ${ }^{45}$ analyzed the re-expansion loss, friction loss, mass flow loss, and heat transfer loss of a compressor using a mathematical model; additionally, the compressor efficiency and energy loss were predicated under various conditions. The friction loss of the compressor was proved to be proportional to the rotation speed, and the heat transfer led to a decrease of $20 \%$ in volumetric efficiency. A significant decrease was caused by suction and discharge, ${ }^{45}$ from which the efficiency can be improved. Under the current situations and scenarios, adiabatic efficiency of the ORP compressor is lower than other types of compressors, although the specific mass flow rate is higher than $0.094 \mathrm{~kg} /(\mathrm{s} \cdot \mathrm{L})$. Specific mass flow rate in this paper was defined as the mass flow rate per unit cylinder displacement of the compressor. As presented by the work, ${ }^{34}$ indicated efficiency of a piston compressor was in the range of $52.7-57 \%$, which was higher than the authors' work. ErtesvÅg ${ }^{46}$ compared a crankdrive reciprocating piston compressor and a linear compressor, indicating that volumetric efficiency of the reciprocating piston compressor was higher than the linear compressor. The thermodynamic efficiency of the reciprocating piston compressor was approximately $70 \%$, while it was in the range of $30-45 \%$ for the overall efficiency. In Roskosch's work, ${ }^{47}$ the adiabatic efficiency was approximately $57.5 \%$ under a pressure of 2.0. It is higher than the authors' results, mainly caused by a high rotation 
speed in the authors' investigation where the rotation speed is twice of the value in Roskosch's work. ${ }^{47}$ An oil free twin-screw air compressor designed by Wang et al. ${ }^{48}$ was demonstrated inconsistent with the above-mentioned results that it was recommended to operate at high speeds in order to ensure a high efficiency (maximum efficiency was around $70 \%$ ).

The pressure and mass flow rate of the compressor are suitable for the applications of PEM fuel cell systems. However, adiabatic efficiency of this compressor is slightly lower than other published data. The main reason is that the ORP compressor experiences a small $\mathrm{CA}$ in the discharging process, and the duration in time is short under high rotation speed. The authors believe that the adiabatic efficiency can achieve a significant increase when decreasing the rotation speed. It will be explored in further work. However, a lower rotation speed will lead to a lower mass flow rate, resulting of a bigger size of the PEM fuel cell system. A balance should be made between the rotation speed and the compressor efficiency for its application to the fuel cell system. The compressor efficiency will benefit from a restructure of the outlet pipes to improve the efficiency of the PEM fuel cell system and overall efficiency of fuel cell vehicles.

\section{CONCLUSIONS}

An ORP compressor, as the air supplier of PEM fuel cell systems, is explored under four different scenarios in this paper. The main conclusions are as follows:

(1) The intake process of this ORP compressor experiences $90^{\circ} \mathrm{CA}$ and the discharge duration is less than $90^{\circ} \mathrm{CA}$; in addition, the discharge duration changes with the outlet pressure. This ORP compressor can deliver fluid with high pressure and a high mass flow rate, contributing to decrease in the compressor size.

(2) The in-cylinder pressure profiles show multipeaks, with one peak after the opening of outlet port 2 under scenarios 1,3 , and 4 . The maximum pressure in scenario 2 is approximately $13.0 \mathrm{bar}$, although the outlet pressure is 2.0 bar, which seriously worsens the compressor efficiency and energy economy.

(3) There is a slight backflow in inlet pipes at the start of the intake process, and the intensity is enhanced with compressor outlet pressure. Outlets 1 and 2 dominate the mass flow of the compressor under scenarios 1,3 , and 4. The specific mass flow rate of this compressor is in the range of $0.094-0.113 \mathrm{~kg} \cdot(\mathrm{s} \cdot \mathrm{L})^{-1}$ among the four scenarios.

(4) The outlet pressure shows a small impact on the compressor mass flow rates, with the maximum difference being $4.06 \%$ among the four scenarios; however, it presents a significant effect on energy consumption and adiabatic efficiency. The maximum adiabatic efficiency is $43.96 \%$, which is lower than conventional piston compressors because of its high in-cylinder pressure in the discharging process.

\section{ASSOCIATED CONTENT}

\section{s) Supporting Information}

The Supporting Information is available free of charge at https://pubs.acs.org/doi/10.1021/acsomega.0c03347.

Average in-cylinder temperature of the four scenarios and mass flow rate of system 2 under the four scenarios (PDF)

\section{AUTHOR INFORMATION}

\section{Corresponding Author}

Jianbing Gao - School of Mechanical Engineering, Beijing Institute of Technology, Beijing 100081, China; 이이.org/ 0000-0002-9724-5789; Email: redonggaojianbing@163.com

\section{Authors}

Shikai Xing - School of Vocational and Technical, Hebei Normal University, Shijiazhuang 050024, China

Guohong Tian - Mechanical Engineering Sciences, University of Surrey, Guildford GU2 7XH, U.K.

Meng Zhao - Beijing Institute of Space Launch Technology, Beijing 100744, China

Chaochen Ma - School of Mechanical Engineering, Beijing Institute of Technology, Beijing 100081, China

Complete contact information is available at:

https://pubs.acs.org/10.1021/acsomega.0c03347

\section{Notes}

The authors declare no competing financial interest.

\section{ACKNOWLEDGMENTS}

The authors would like to appreciate the funding support from the Hebei Natural Science Foundation Project (E2019205043); Key Scientific and Technological Research Projects of Colleges and Universities in Hebei Province (ZD2019076); and the Technology Innovation Pre-research Project of Hebei Normal University (L2019K07).

\section{REFERENCES}

(1) Balasubramanian, D.; Arumugam, S. R. S.; Subramani, L.; Chellakumar, I. J. L. J. S.; Mani, A. A numerical study on the effect of various combustion bowl parameters on the performance, combustion, and emission behavior on a single cylinder diesel engine. Environ. Sci. Pollut. Res. 2018, 25, 2273-2284.

(2) Zhang, Y.; Guo, C.; Li, G.; Liu, Y.; Chen, Z. Cooperative control strategy for plug-in hybrid electric vehicles based on a hierarchical framework with fast calculation. J. Cleaner Prod. 2020, 251, 119627.

(3) Sogut, M. Z.; Seçgin, Ö.; Ozkaynak, S. Investigation of thermodynamics performance of alternative jet fuels based on decreasing threat of paraffinic and sulfur. Energy 2019, 181, 11141120.

(4) Gao, J.; Tian, G.; Sorniotti, A.; Karci, A. E.; Di Palo, R. Review of thermal management of catalytic converters to decrease engine emissions during cold start and warm up. Appl. Therm. Eng. 2019, $147,177-187$.

(5) Gao, J.; Ma, C.; Xing, S.; Sun, L.; Liu, J. Polycyclic aromatic hydrocarbon emissions of non-road diesel engine treated with nonthermal plasma technology. Korean J. Chem. Eng. 2016, 33, 3425-3433.

(6) Fernández, R. Á.; Caraballo, S. C.; Cilleruelo, F. B.; Lozano, J. A. Fuel optimization strategy for hydrogen fuel cell range extender vehicles applying genetic algorithms. Renewable Sustainable Energy Rev. 2018, $81,655-668$.

(7) Taner, T. Energy and exergy analyze of PEM fuel cell: a case study of modeling and simulations. Energy 2018, 143, 284-294.

(8) Ahmadi, S.; Bathaee, S. M. T.; Hosseinpour, A. H. Improving fuel economy and performance of a fuel-cell hybrid electric vehicle (fuelcell, battery, and ultra-capacitor) using optimized energy management strategy. Energy Convers. Manage. 2018, 160, 74-84.

(9) Zhao, D.; Xu, L.; Huangfu, Y.; Dou, M.; Liu, J. Semi-physical modeling and control of a centrifugal compressor for the air feeding of a PEM fuel cell. Energy Convers. Manage. 2017, 154, 380-386.

(10) Yu, W.; Sichuan, X.; Ni, H. Air compressors for fuel cell vehicles: An systematic review. SAE Int. J. Alt. Power. 2015, 4, 115-122.

(11) Moore, R. M.; Hauer, K. H.; Friedman, D.; Cunningham, J.; Badrinarayanan, P.; Ramaswamy, S.; Eggert, A. A dynamic simulation 
tool for hydrogen fuel cell vehicles. J. Power Sources 2005, 141, 272285 .

(12) Fang, G.; Du, J.; Chan, M.-y.; Deng, S. Study on the Scroll Compressors Used in the Air and Hydrogen Cycles of FCVs by CFD Modeling, 2018.

(13) Sun, H.; Hu, H.; Wu, J.; Ding, G.; Li, G.; Wu, C.; Wang, X.; Lv, Z. A theory-based explicit calculation model for variable speed scroll compressors with vapor injection. Int. J. Refrig. 2018, 88, 402-412.

(14) Acharya, P. Temperature Abatement using Spray Injection in Liquid Piston Compressors for Ocean Compressed Air Energy Storage Systems. M. Sc Thesis, North Carolina State University, 2018.

(15) Qi, L.; Geng, H.; Zhang, J.; Du, T.; Lv, H.; Yu, L. Design and Research of a Centrifugal Compressor for Automotive Fuel Cell Systems. 2018 IEEE International Conference on Mechatronics and Automation (ICMA); IEEE, 2018; pp 1777-1781.

(16) He, Y.; Xing, L.; Zhang, Y.; Zhang, J.; Cao, F.; Xing, Z. Development and experimental investigation of an oil-free twin-screw air compressor for fuel cell systems. Appl. Therm. Eng. 2018, 145, 755762.

(17) Wang, C.; Xing, Z.; Chen, W.; Sun, S.; He, Z. Analysis of the leakage in a water-lubricated twin-screw air compressor. Appl. Therm. Eng. 2019, 155, 217-225.

(18) Hao, H.; Liu, Z.; Zhao, F.; Li, W.; Hang, W. Scenario analysis of energy consumption and greenhouse gas emissions from China's passenger vehicles. Energy 2015, 91, 151-159.

(19) Kotlov, A.; Kuznetsov, L.; Burakov, A. Analysis of reciprocating booster compressor performance by mathematical modelling methods. AIP Conference Proceedings; AIP Publishing, 2019; p 030012.

(20) Mi, X.; Li, Q.; Wang, F.; Zhao, X. Flow field simulation of reciprocating compressor based on dynamic mesh technology. 2017 IEEE 21st International Conference on Computer Supported Cooperative Work in Design (CSCWD); IEEE, 2017; pp 567-572.

(21) Otechos. 2017, https://www.otechos.com.

(22) Caskey, S. L.; Groll, E. A. Study of Novel Rotary Cylinder Compressor, 2018.

(23) Gao, J.; Tian, G.; Jenner, P.; Burgess, M.; Emhardt, S. Preliminary explorations of the performance of a novel small scale opposed rotary piston engine. Energy 2020, 190, 116402.

(24) Ma, Y.; He, Z.; Peng, X.; Xing, Z. Experimental investigation of the discharge valve dynamics in a reciprocating compressor for transcritical CO2 refrigeration cycle. Appl. Therm. Eng. 2012, 32, 13-21.

(25) Maulit, R.; San, O.; Bach, C. K. Thermodynamic modelling of reciprocating and Wankel type compressor for household refrigerators, 2018.

(26) Arques, P. Piston movement in thermocompressor. IECEC-97 Proceedings of the Thirty-Second Intersociety Energy Conversion Engineering Conference (Cat. No. 97CH6203); IEEE, 1997; pp 1003-1008.

(27) Hou, X.; Zhang, H.; Xu, Y.; Yu, F.; Zhao, T.; Tian, Y.; Yang, Y.; Zhao, R. External load resistance effect on the free piston expanderlinear generator for organic Rankine cycle waste heat recovery system. Appl. Energy 2018, 212, 1252-1261.

(28) Habeeb, L. J.; Saleh, F. A.; Maajel, B. M. Numerical Simulation of 3-D One-Way Fluid-Structure Interaction in a Tube with Twisted Tape under Laminar and Turbulent Flow Regime. Int. J. Appl. Eng. Res. 2018, 13, 13622-13631.

(29) Wei, M.; Song, P.; Zhao, B.; Shi, L.; Wang, Z.; Ma, C. Unsteady flow in the suction process of a scroll expander for an ORC waste heat recovery system. Appl. Therm. Eng. 2015, 78, 460-470.

(30) ANSYS. ANSYS Fluent Theory Guide, Release 15.0, 2013.

(31) Gao, J.; Tian, G.; Jenner, P.; Burgess, M. Intake characteristics and pump loss in the intake stroke of a novel small scale opposed rotary piston engine. J. Cleaner Prod. 2020, 261, 121180.

(32) Hu, X.; Qu, Z.; Yang, X.; Sun, J. Theoretical study on frictional losses of a novel automotive swing vane compressor. Int. J. Refrig. 2013, 36, 758-767.

(33) Yanagisawa, T.; Shimizu, T. Friction losses in rolling piston type rotary compressors. III. Int. J. Refrig. 1985, 8, 159-165.

(34) Stouffs, P.; Tazerout, M.; Wauters, P. Thermodynamic analysis of reciprocating compressors. Int. J. Therm. Sci. 2001, 40, 52-66.
(35) Shen, L.; Wang, W.; Wu, Y.; Cheng, L.; Lei, B.; Zhi, R.; Ma, C. Theoretical and experimental analyses of the internal leakage in singlescrew expanders. Int. J. Refrig. 2018, 86, 273-281.

(36) Qin, Y.; Du, Q.; Fan, M.; Chang, Y.; Yin, Y. Study on the operating pressure effect on the performance of a proton exchange membrane fuel cell power system. Energy Convers. Manage. 2017, 142, $357-365$.

(37) Tekin, M.; Hissel, D.; Pera, M.-C.; Kauffmann, J.-M. Energy consumption reduction of a PEM fuel cell motor-compressor group thanks to efficient control laws. J. Power Sources 2006, 156, 57-63.

(38) Zhao, D.; Blunier, B.; Gao, F.; Dou, M.; Miraoui, A. Control of an ultrahigh-speed centrifugal compressor for the air management of fuel cell systems. IEEE Trans. Ind. Appl. 2014, 50, 2225-2234.

(39) Galindo, J.; Climent, H.; Guardiola, C.; Tiseira, A. On the effect of pulsating flow on surge margin of small centrifugal compressors for automotive engines. Exp. Therm. Fluid Sci. 2009, 33, 1163-1171.

(40) Koh, D.-Y.; Hong, Y.-J.; Park, S.-J.; Kim, H.-B.; Lee, K.-S. A study on the linear compressor characteristics of the Stirling cryocooler. Cryogenics 2002, 42, 427-432.

(41) Barth, E. J.; Riofrio, J. Dynamic Characteristics of a Free Piston Compressor. ASME 2004 International Mechanical Engineering Congress and Exposition (IMECE), 2004; pp 13-19.

(42) Elhaj, M.; Gu, F.; Ball, A. D.; Albarbar, A.; Al-Qattan, M.; Naid, A. Numerical simulation and experimental study of a two-stage reciprocating compressor for condition monitoring. Mech. Syst. Signal Pr. 2008, 22, 374-389.

(43) Zhang, Y.; Bao, P.; Wan, Y.; Xu, S. Modeling and analysis of air supply system of polymer electrolyte membrane fuel cell system. Energy Procedia 2017, 142, 1053-1058.

(44) Han, J.; Yu, S.; Yi, S. Adaptive control for robust air flow management in an automotive fuel cell system. Appl. Energy 2017, 190, $73-83$.

(45) Park, Y. C. Transient analysis of a variable speed rotary compressor. Energy Convers. Manage. 2010, 51, 277-287.

(46) ErtesvÅg, I. S. Analysis of the Vading concept-a new rotary-piston compressor, expander and engine principle. Proc. Inst. Mech. Eng., Part A 2002, 216, 283-290.

(47) Roskosch, D.; Venzik, V.; Atakan, B. Thermodynamic model for reciprocating compressors with the focus on fluid dependent efficiencies. Int. J. Refrig. 2017, 84, 104-116.

(48) Wang, C.; Xing, Z.; Chen, W.; Yang, Q.; He, Z. Development of an oil free water-lubricated twin-screw air compressor. Appl. Therm. Eng. 2018, 143, 396-402. 